\title{
Awareness regarding diabetes mellitus among individuals attending a hospital, Bhaktapur
}

\section{Kafle R', Pradhan $\mathrm{B}^{2}$, Chandyo RK ${ }^{3}$}

${ }^{1}$ Rita Kafle, Lecturer, ${ }^{2}$ Binita Pradhan, Associate Professor, Department of General Practice and Emergency; ${ }^{3}$ Ram Krishna Chandyo, Associate Professor, Department of Community Medicine; Kathmandu Medical College Teaching Hospital, Kathmandu, Nepal.

\begin{abstract}
Background: Diabetes mellitus is the most prevalent metabolic condition and one of the major health and socioeconomic problems worldwide. Awareness of risk factors and prevention of diabetes plays a major role for prevention of diabetes mellitus in general population.

Objectives: To assess level of awareness regarding diabetes mellitus risk factors and preventive measures among individuals who attended General Practice outpatient department at Kathmandu Medical College Teaching Hospital, Duwakot, Bhaktapur.

Methodology: This is a descriptive study conducted in Department of General Practice and Emergency of Kathmandu Medical College Teaching Hospital. The study included 370 patients attending General Practice outpatient department from November 2018 to April 2019. The data collected was entered in the Statistical Package for the Social Sciences software and analysed for results. Ethical clearance was taken from Institutional Review Committee of Kathmandu Medical College.

Results: The study included 370 participants; the mean age was $40.83 \pm 12.21$ years. More than half of the participants (56.5\%) were females and $43.5 \%$ were males. The most commonly mentioned risk factor was lack of physical activity and obesity. Almost $80 \%$ participants correctly stated that physical activity could help prevent diabetes mellitus. There was no statistical significance between awareness and educational level of participants.

Conclusion: This study showed that proper awareness programs need to be carried out in rural and urban communities to prevent diabetes and its complications. In this study, patient awareness about risk factors and preventive measures was not appreciable. Association of awareness with age, sex and education level was not statistically significant.
\end{abstract}

Key words: Awareness; Diabetes mellitus; Knowledge.

DOI: https://doi.org/10.3126/jkmc.v8i2.28173

\section{INTRODUCTION}

D iabetes mellitus (DM) is a metabolic condition resulting in hyperglycemia and hyperglycemia related complications. It is due to defect in insulin secretion that affects the Beta cells function located in the pancreas, resulting in an increased level of glucose in blood'. It is a major chronic health problem throughout the world and increases the risk of microvascular, macrovascular complications and early death in general population ${ }^{2}$. It is now recognized as a major chronic

Address for correspondence

Dr. Rita Kafle

Lecturer, Department of General Practice and Emergency

Kathmandu Medical College Teaching Hospital

Sinamangal, Kathmandu, Nepal

E-mail:dr.rkafle@gmail.com health problem throughout the world affecting a large number of people in a wide range of ethnic and economic levels in both developed and developing countries.

Prevalence of diabetes is rising all over the world and Nepal due to urbanization, increased obesity, physical inactivity and sedentary lifestyles ${ }^{3}$. It is expected that the prevalence of diabetes will increase dramatically by 2030 worldwide, and the increase in rate will be more in South East Asia countries ${ }^{4}$. Prevalence of diabetes in south east Asia is $8.33 \%$ and National prevalence of Nepal is $4.58 \% 5$. Diabetes causes significant morbidity and mortality from effects on cardiac function, damage visual impairment and blindness $s^{6-9}$. Evidence suggests that diabetes is potentially preventable if modifiable risk factors like 
physical inactivity, unhealthy diet, overweight, high blood pressure, smoking and alcohol use are identified early and avoided ${ }^{10-12}$. Management of diabetes include both prevention and treatment. There is clear evidence that increasing physical activity, balancing body weight, eating healthy or diabetic diet and using medications are possible options to prevent or delay diabetes. Hence, an important step to stop the increasing rate of diabetes mellitus is to raise public awareness of the disease $e^{4}$.

The high incidence of diabetes mellitus in Nepal was found to be due to lack of public awareness and poor medical service in the country ${ }^{13}$. The risk of developing type 2 diabetes is determined by some modifiable factors related to rapid urban growth, changing lifestyle (obesity, sedentary lifestyle, diet, smoking, physical and emotional stress) and non-modifiable factors (family history of diabetes, age, race/ethnicity) ${ }^{14}$. Awareness of modifiable risk factors for diabetes and preventive measures is the first step in prevention and will enable the public to make an informed decision of adopting a healthy lifestyle ${ }^{15-18}$. This study is therefore, conducted to assess the knowledge of diabetes mellitus risk factors and preventive measures which will help for further public awareness and implementation of health education programs. Therefore, with changing life style, it is justifiable to carry out such study in Nepalese population.

\section{METHODOLOGY}

\section{Study design and setting}

This is a descriptive study to learn about the awareness of risk factors and preventive measures of diabetes mellitus, conducted in General Practice outpatient department of Kathmandu Medical College Teaching Hospital, Duwakot, Bhaktapur.

\section{Study participants}

The study participants of the study were patients of age 20-60 years, who visited the General Practice outpatient department. Patients having history of diabetes mellitus were excluded. National Population Census 2011 showed the population of Duwakot to be 10461. Sample size of 370 was calculated using confidence interval of $5 \%$ in 10461 population.

Sample size, $s s=\frac{z^{2} \times P \times(1-P)}{c^{2}}$

where $s s=$ Sample Size, $p=$ Percentage of picking choice (Taken as 0.5), c=Confidence interval (expressed in decimal), $z=1.96$ taking standard deviation of confidence level (5\%)

\section{Study tools}

A semi-structured questionnaire was adapted from surveys done in Nepal by Gautam et al ${ }^{19}$. Questionnaire included patient profile parameters like age, gender, education and 16 questions. Eight questions to assess risk factors and eight questions to assess preventive measures were used. Each correct answer was given a score 1 and 0 was given for a wrong answer.

\section{Data collection}

Data was collected by interviewing patients who resided in Duwakot and met the inclusion criteria by using a semi-structured questionnaire. A written consent was taken from all participants before taking data after explaining about the research. Questionnaire was filled by the researchers by face to face interview in the General Practice outpatient department (OPD). Purposive sampling technique was used and data was collected for six months from November 2018 to April 2019.

\section{Data analysis}

The obtained data was entered and analysed using Statistical Package for the Social Sciences (SPSS) version 16. All statistical tests were performed using 0.05 as the level of significance. Age group was categorised as less than 40 years and more than 40 years. Education level was categorised as illiterate, primary (up to class five), secondary (from class five to class 12), Bachelors, Masters and above. Frequency distribution table was prepared to interpret the data. Independent t-test and one way ANOVA (analysis of variance) test were used for analysing the association between variables.

\section{RESULTS}

This study comprised of a total of 370 patients who visited the General Practice outpatient department over a period of six months. The mean age was $40.83 \pm 12.21$ years, and percentage of females and males were $56.5 \%$ and $43.5 \%$ respectively. Majority of participants $(41.2 \%)$ had secondary education level.

Assessing the knowledge about risk factors of diabetes mellitus (Table 1), most of the participants were aware that lack of physical exercise, obesity, family history and hypertension $(72.7 \%, 68.7 \%, 68.1 \%, 58.6 \%$ respectively) are risk factors.

Regarding the knowledge about prevention (Table 2), majority of participants $(71.9 \%, 68.4 \%, 68.4 \%, 61.9 \%$ respectively) knew that diabetes mellitus could be prevented by (physical activity, low carbohydrate diet, 
weight reduction, managing blood pressure), while more than half $(53.5 \%)$ did not know that quitting smoking is one of the preventive measures.

Table 3 and 4 showed relationship between age, sex, and educational level with awareness of risk factors and preventive measures which showed no statistical significance.

Table 1:Knowledge of risk factors of diabetes mellitus

\begin{tabular}{lcc}
\hline $\begin{array}{l}\text { Knowledge of Risk } \\
\text { Factors of Diabetes }\end{array}$ & \multicolumn{2}{c}{ Correct response } \\
Mellitus & Number & Percentage (\%) \\
Family history & 252 & 68.1 \\
\hline Increasing age & 233 & 63 \\
\hline Lack of physical exercise & 269 & 72.7 \\
\hline Obesity & 254 & 68.7 \\
\hline Smoking & 160 & 43.3 \\
\hline Mental stress & 192 & 51.9 \\
\hline Hypertension & 217 & 58.6 \\
\hline High cholesterol & 212 & 57.3 \\
\hline
\end{tabular}

Table 2: Knowledge regarding preventive measures of diabetes mellitus

\begin{tabular}{|c|c|c|}
\hline \multirow{2}{*}{$\begin{array}{l}\text { Knowledge regarding } \\
\text { preventive measures } \\
\text { of Diabetes Mellitus }\end{array}$} & \multicolumn{2}{|c|}{ Correct response } \\
\hline & Number & Percentage (\%) \\
\hline Physical activity & 266 & 71.9 \\
\hline Weight reduction & 253 & 68.4 \\
\hline Stress reduction & 220 & 59.5 \\
\hline Low carb diet & 253 & 68.4 \\
\hline Quitting alcohol & 199 & 53.8 \\
\hline Quitting smoking & 172 & 46.5 \\
\hline $\begin{array}{l}\text { Managing high blood } \\
\text { pressure }\end{array}$ & 229 & 61.9 \\
\hline Lowering cholesterol & 198 & 53.5 \\
\hline
\end{tabular}

Table 3: Knowledge of risk factors of diabetes mellitus in relation to age, sex and education

\begin{tabular}{lcc}
\hline Variables & $\begin{array}{c}\text { Knowledge of } \\
\text { diabetes mellitus risk } \\
\text { factors (Mean } \pm \text { SD) }\end{array}$ & p-value \\
\hline Sex & $4.67 \pm 2.12$ & \\
Male & $4.95 \pm 2.34$ & 0.23 \\
Female & & \\
Age(years) & $4.99 \pm 2.13$ & $0.18^{*}$ \\
$<40$ & $4.68 \pm 2.35$ & \\
$>40$ &
\end{tabular}

\begin{tabular}{|c|c|c|}
\hline \multicolumn{3}{|l|}{ Education } \\
\hline Illiterate & $4.35 \pm 2.75$ & \\
\hline Primary & $4.79 \pm 2.20$ & \\
\hline Secondary & $4.96 \pm 1.98$ & $0.23^{\prime \prime}$ \\
\hline Bachelors & $5.17 \pm 2.10$ & \\
\hline Masters and above & $5.00 \pm 2.58$ & \\
\hline
\end{tabular}

* Independent t test ; ^ One way ANOVA

Table 4: Knowledge of preventive measures of DM in relation to age, sex and education

\begin{tabular}{lcc}
\hline Variables & $\begin{array}{c}\text { Knowledge of DM } \\
\text { preventive measures } \\
\text { (Mean } \pm \text { SD) }\end{array}$ & p-value \\
\hline Sex & $4.95 \pm 2.56$ & 0.42 \\
Male & $4.73 \pm 2.64$ & \\
Female & & \\
Age(years) & $4.94 \pm 2.48$ & \\
$<40$ & $4.72 \pm 2.72$ & $0.40^{*}$ \\
$>40$ & & \\
Education & $4.23 \pm 2.83$ & \\
Illiterate & $4.79 \pm 2.56$ & $0.20^{\wedge}$ \\
Primary & $5.02 \pm 2.44$ & \\
Secondary & $5.05 \pm 2.63$ & \\
Bachelors & $5.31 \pm 2.84$ & \\
Masters and above &
\end{tabular}

\section{DISCUSSION}

Awareness of the risk factors of diabetes mellitus can assist in its early prevention and reduce its incidence. Level of awareness depends on socioeconomic gradient, culture and ethnic variation. Understanding of these variables is highly important in designing strategies for the prevention of diabetes. The findings of the present study were quite similar to the findings of study conducted by Wee et al in Singapore ${ }^{15}$ on knowledge of risk factors of diabetes in different population groups. Majority of the participants agreed that lack of physical exercise, obesity and family history are risk factors, which was similar to the study done in Saudi Arabia ${ }^{16}$. In our study, $68.7 \%$ reported obesity as a risk factor, compared to a study in Chennai done by Mohan D et al ${ }^{17}$, where only $12 \%$ of subjects knew that obesity and lack of physical activity were risk factors. Our study population dealt with educated population which may have led to higher percentage of knowledge.

Weight reduction and physical activity were frequently mentioned measures relating to prevention of DM. Contradicting observation was reported in a study by Foma et $\mathrm{al}^{18}$, where only minority of them thought that weight loss and exercise were important measures in preventing DM. 
In the present study, relationship between educational level, awareness of DM risk factors and preventive measures reveal no statistical significance in contrary to a study done in Bangladesh by Shirin et al ${ }^{19}$ where level of education showed significant effect on knowledge of participants. However, participants who were illiterate had low level of awareness though statistically not significant. This reflected that formal education alone cannot change the knowledge of risk factors and prevention. Therefore, continuous medical education program for general population is required. Creating awareness about DM through the internet, magazines and books could be helpful. Recent studies like Diabetes Prevention Program, the Finnish Diabetes Prevention study ${ }^{20}$, clearly demonstrated that diabetes is a preventable disease, yet lack of knowledge in the educated population still showed that more effort is required for transmitting this important health message to the general population.

\section{REFERENCES}

1. Mehta RS, Karki P, Sharma SK. Risk factors, associated health problems, reasons for admission and knowledge profile of diabetes patients admitted in BPKIHS. Kathmandu University Medical Journal (KUMJ). 2006;4(1):11-3.

2. Schramm TK, Gislason GH, Kober L et al. Diabetes patients requiring glucose-lowering therapy and non-diabetics with a prior myocardial infarction carry the same cardiovascular risk a population study of 3.3 million people. Circulation. 2008;117(15):194554.[DOI]

3. Ansari S, Samaga S, Rao S, Gowda S, Mohammed T, Atrolia $S$, et al.Awareness of risk factors of diabetes and practices regarding its prevention among the adolescents.Nitte University Journal of Health Science NUJHS.2014;4.

4. Al-Dahan SM, Albaik M, Alomran Y, Aldahan F, Albaik S. Awareness and Knowledge of Diabetes among AlWazarat Family Medicine Health Center Attendants. American Journal of Research Communication. 2013;1(12):104-30.

5. Intenational Diabetes Federation:IDF Diabetes Atlas, 6th edition, Brussels, Belgium: International Diabetes Federation, 2013. Available from: http://www.idf. org/diabetesatlas/update-2014.

6. Icks A, Haastert B, Trautner C, Giani G, Glaeske G, Hoffmann F. Incidence of lower-limb amputations in the diabetic compared to the non-diabetic population.ExpClinEndocrinol Diabetes. 2009;117(09):500-4.[DOI]
This study however, represents only a small tip of iceberg, showing a small scenario of Duwakot. Similar studies done on a large representative sample will be a true reflection of the situation of Nepal. This is a single tertiary hospital-based study and hence the result may not be a true reflection of all population. Closed ended questions can sometimes be guessed by respondents which can result in biasness.

\section{CONCLUSION}

In this study, patient awareness about risk factors and preventive measures was not appreciable. Association of awareness with age, sex and education level was not statistically significant. This suggests the need of awareness programs for patients, both literate and illiterate to improve their knowledge regarding diabetes for better health promotion.

7. Resnikoff S, Pascolini D, Etya'ale D, Kocur I, Pararajasegaram R, Pokharel GP,et al. Global data on visual impairment in the year 2002. Bulletin World Health Organ. 2004;82(11):844-51.[DOI]

8. Lawes C, Parag V, Bennett D, Suh I, Lam T, Whitlock $\mathrm{G}$, et al. Blood glucose and risk of cardiovascular disease in the Asia Pacific region. Diabetes Care.2004;27(12):2836-42.[DOI]

9. Khaw KT, Wareham N, Bingham S, Luben R, Welch A, Day N. Association of hemoglobin A1c with cardiovascular disease and mortality in adults: the European prospective investigation into cancer in Norfolk. Annals Internal Medicine. 2004;141(6):41320.[DOI]

10. Yamaoka K, Tango T. Efficacy of lifestyle education to prevent type 2 diabetes. Diabetes Care. 2005;28(11):2780-86.[DOI]

11. The Diabetes Prevention Program (DPP): Description of lifestyle intervention. Diabetes Care. 2002; 25:2165-71.[DOI]

12. Gillies C, Abrams K, Lambert PC, Cooper NJ, Sutton AJ, Hsu RT, et al. Pharmacological and lifestyle interventions to prevent or delay type 2 diabetes in people with impaired glucose tolerance: systematic review and meta-analysis. BMJ. 2007; 334(7588):299. [DOI]

13. Karki $P$, Baral N, Lamsal M, Rijal S, Koner BC, Dhungel $\mathrm{S}$, et. Al. Prevalence of Non insulin dependent Diabetes Mellitus in urban areas of Eastern Nepal: A hospital based study. South East Asian Journal of Tropical Medicine and Public health .2000;31(1):1636. 
14. Hussain A, Claussen B, Ramachandran A, Williams R. Prevention of type 2 diabetes: a review. Diabetes Res Clin Pract. 2006;76:317-26. [DOI]

15. Bowman BA, Gregg EW, Williams DE, Engelgau $M M$, Jack $L$ Jr. Translating the science of primary, secondary, and tertiary prevention to inform the public health response to diabetes.J Public Health ManagPract. 2003 Nov;9:S8-S14. (suppl). [DOI]

16. Garfield S, Malozowski S, Chin M, Venkat KN, Glasgow $\mathrm{R}$, Green $\mathrm{RH}$, et al.Considerations for diabetes translation research in real-world settings. Diabetes Care. 2003 Sep;26(9):2670-74.[DOI]

17. Venkat Narayan K, Benjamin E, Gregg E, Norris S, Engelgau M. Diabetes translation research: where are we and where do we want to be? Ann Intern Med. 2004; 140:958-63.[DOI]

18. Glasgow RE, Wagner E, Kaplan RM, Vinicor F, Smith L, Norman J, et al.If diabetes is a public health problem, why not treat it as one? A populationbased approach to chronic illness. Ann Behav Med. 1999;(2):159-70. [DOI]

19. Gautam A, Bhatta DN, Aryal UR.Diabetes related health knowledge, attitude and practice among diabetic patients in Nepal. BMC Endocrine Disord. 2015 June; 15:25. [DOI]
20. Wee HL, Ho HK, Li SC. Public awareness of diabetes mellitus in Singapore. Singapore Med J. 2002;43(3):128-34.

21. Aljoudi AS, Taha AZA. Knowledge of diabetes risk factors and preventive measures among attendees of a primary care center in eastern Saudi Arabia. Ann Saudi Med. 2009;29(1):15-9. [DOI]

22. Mohan D, Raj D, Shanthirani CS, Datta $M$, et al.Awareness and knowledge of diabetes in Chennaithe Chennai Urban Rural epidemiology study. J Assoc Physicians India. 2005;53:283.

23. Foma MA, Saidu Y, Omoleke SA, Jafali J. Awareness of diabetes mellitus among diabetic patients in the Gambia: a strong case for health education and promotion. BMC Public Health. 2013;13:1124. [DOI]

24. Mumu SJ, Saleh F, Ara F, Haque MR, Ali L. Awareness regarding risk factors of type 2 diabetes among individuals attending a tertiary-care hospital in Bangladesh: a cross-sectional study. BMC Research Notes.2014;7:599. [DOI]

25. Lindstrom J, Louheranta A, Mannelin M, Rastas M, Salminen V, Eriksson J,et al.; Finnish Diabetes Prevention Study Group. The Finnish Diabetes Prevention Study (DPS): Lifestyle intervention and 3 -year results on diet and physical activity. Diabetes Care. 2003 Dec;26(12):3230-6.[DOI] 